\title{
Implementasi Pembelajaran Kooperatif NHT Menggunakan Media Hypertext Untuk Meningkatkan Kreativitas dan Pencapaian Akademik Peserta Didik Mata Pelajaran Sejarah XI IPS di SMAN 1 Jenggawah (Implementation of Cooperative Learning NHT With Hypertext Media to Improve Students' Creativity And Achievement History of XI IPS 1 at SMAN 1 Jenggawah)
}

\author{
Aydha Vadillah Kurniawati, Mohamad Na'im, Bambang Soepeno \\ Pendidikan Sejarah, Fakultas Keguruan dan Ilmu Pendidikan, Universitas Jember (UNEJ) \\ Jln. Kalimantan 37, Jember 68121 \\ E-mail: mohamadnaim@unej.ac.id
}

\begin{abstract}
Abstrak
Dewasa ini, pengajaran mata pelajaran sejarah bagi siswa dituntut aktif dan kreatif, perlu adanya perbaikan yaitu penggunaan model pembelajaran kooperatif jenis NHT dengan media hypertext. Tujuannya adalah untuk menunjang pertumbuhan kreativitas dan hasil belajar peserta didik. Penelitian ini merupakan penelitian tindakan kelas dengan model Hopkins dengan 4 tahap setiap siklus yang dilakukan 3 siklus. Subyek penelitian adalah XI IPS I SMAN 1 Jenggawah dengan total 40 siswa. Data yang diperoleh dianalisis secara kuantitatif. Kreativitas diukur dengan 4 indikator sementara hasil belajar diukur dari siklus uji akhir. Hasil penelitian kreativitas pada peserta didik adalah: berfikir lanear berfikir 70\%, berpikir fleksibilitas $72 \%$, berpikir asli 75\%, memikirkan elaborasi $72 \%$. Hasil pembelajaran pada siklus $1,52,5 \%$, siklus $276,31 \%$, siklus $382,05 \%$. Berdasarkan hasil penelitian, dapat disimpulkan bahwa penerapan model pembelajaran kooperatif tipe NHT dengan media hypertext dapat meningkatkan kreativitas dan hasil pembelajaran sejarah. Manfaat dari penelitian ini terkait dengan model pembelajaran kooperatif tipe NHT dengan media hypertext, kreativitas dan hasil belajar.
\end{abstract}

Kata Kunci: Kooperatif Learning tipe NHT, Media Hypertext, Kreatifitas, Pencapaian Akademik

\section{Abstract}

Nowadays, teaching history subject for the students is demanded active and creative, it needs an improvement that is the use of cooperative learning model of NHT type with hypertext media. The aim is to support the growth of creativity and learning outcomes of learners. This research is a classroom action research using Hopkins model with 4 stage each cycle which is done 3 cycle. The subjects of the study were class XI IPS I SMAN 1 Jenggawah with a total 40 students. The data obtained were analyzed quantitatively. Creativity is measured by 4 indicators while learning outcomes are measured from the final test cycle. The result of creativity study on the learners are: fluency thinking 70\%, fleksibility thinking 72\%, thinking original $75 \%$, thinking elaboration $72 \%$. Learning outcomes at cycle 1 52,5\%, cycle 276,31\%, cycle $382,05 \%$. Based on the research result, it can be concluded that the implementation of NHT type cooperative learning model with hypertext media can improve creativity and the result of history learning. The benefits of this study can be used as reference in learning history and sources for other researchers related with NHT type cooperative learning model with hypertext media, creativity and learning outcomes.

Keywords: cooperative learning of NHT type, Hypertext media, creativity, achievement

\section{Pendahuluan}

Pembelajaran sejarah lebih menekankan peserta didik untuk lebih kreatif, pendidik diharapkan dapat menumbuhkan kreativitas peserta didik, sehingga melalui pembelajaran sejarah kemampuan kreativitas peserta didik mampu melaksanakan konstruksi materi pembelajaran sejarah dengan baik [1]. Namun pada faktanya pembelajaran masih berfokus pada pendidik sebagai peran utama, penggunaan ceramah sebagai model pembelajaran di kelas.

Berdasarkan hasil observasi awal dan wawancara, bahwa sejauh ini minat peserta didik terhadap pelajaran sejarah di kelas XI IPS masih tergolong rendah, serta kreativitas peserta didik yang masih kurang yang mempengaruhi hasil belajar peserta didik rendah. diperoleh permasalahan kreativitas peserta didik kelas XI IPS 1 yaitu meliputi: (1) kelancaran berpikir sebesar 58\%; (2) keluwesan berpikir sebesar 61\%; (3) berpikir orisinil sebesar 61\%; (4) berpikir terperinci sebesar 59\%. Permasalahan tersebut merupakan bukti bahwa kreativitas peserta didik dalam pembelajaran masih rendah.

Hasil studi dokumenter yang diperoleh dari pendidik mata pelajaran sejarah di SMAN 1 Jenggawah pada tanggal 5 Desember 2016 diketahui rata-rata nilai ulangan harian kelas XI IPS sebagai berikut: XI IPS $1=69,77$, XI IPS $2=77,35$, dan XI IPS $3=74,32$. Presentase ketuntasan hasil belajar yang diperoleh XI IPS 1 yaitu $35 \%$ peserta didik dikategorikan berhasil dengan jumlah 14 peserta didik dan 65 $\%$ tidak tuntas belajar dengan jumlah 26 peserta didik. Kelas dengan nilai terendah yaitu kelas XI IPS 1 terlihat dari 
banyaknya peserta didik yang mendapat nilai dibawah KKM yaitu 75. Dengan demikian, peneliti lebih memfokuskan untuk melakukan tindak lanjut penelitian di kelas XI IPS 1 berdasarkan hasil belajar yang paling rendah dan minat belajar sejarah yang kurang.

Pendidik hanya menerapkan metode ceramah dengan memanfaatkan papan tulis sebagai media menyampaikan materi pada saat proses pembelajaran. Kondisi cenderung kurang aktif diperlihatkan peserta didik pada saat memperhatikan penjelasan pendidik, kurang kreatif dalam bertanya ketika diberi kesempatan, cenderung tidak menjawab pertanyaan yang diajukan pendidik maupun pada saat berdiskusi. Peserta didik memiliki keraguan dalam menayakan materi kepada pendidik meskipun mereka belum paham akan materi yang dijelaskan. Hal tersebut dikarenakan peserta didik memiliki rasa keingintahuan yang kurang akan materi pelajaran yang sedang dipelajari. Untuk mengatasi permasalahan tersebut dapat dilakukan dengan merubah cara mengajar pendidik dengan menerapakan model pembelajaran yang melibatkan peserta didik aktif yaitu dengan pembelajaran kooperatif dengan model NHT dan penggunaan Hypertext sebagai media pembelajaran.

Numbered Head Together dikembangkan oleh Spencer Kagan tahun 1992 dimana model pembelajaran ini dilakukan dengan cara belajar secara bersama-sama yang akan membantu mempercepat belajar peserta didik dalam proses pembelajaran [2]. Langkah-langkah pembelajaran kooperatif tipe numbered head together adalah pemberian nomor kepala, pengajuan pertanyaan, bekerja sama dalam kelompok dan menjawab pertanyaan yang sudah didiskusikan. Pembelajaran ini dimulai dengan mengorganisasikan peserta didik ke dalam beberapa kelompok dan setiap peserta didik diberi nomor. Pendidik memberi soal kepada peserta didik untuk di diskusikan bersama anggota kelompok dan setiap peserta didik harus menguasai dan memahami jawaban dari setiap soal. Selanjutnya pendidik memanggil peserta didik berdasarkan nomor untuk menjawab soal [2]. Media Hypertext dapat disimpulkan bahwa media Hypertext adalah sebuah tautan yang menghubungkan beberapa kata atau kalimat dalam suatu dokumen ke dokumen lain dengan menggunakan link.

Berdasarkan hal tersebut maka dilakukan penelitian dengan menggunakan rumusan masalah: 1) apakah penerapan model pembelajaran kooperatif tipe numbered head together dengan media hypertext dapat meningkatkan kreativitas pesera didik dalam pembelajaran sejarah kelas XI IPS 1 SMAN 1 Jenggawah tahun ajaran 2016/2017; 2) apakah penerapan model pembelajaran kooperatif tipe numbered head together dengan media hypertext dapat meningkatkan hasil belajar pesera didik dalam pembelajaran sejarah kelas XI IPS 1 SMAN 1 Jenggawah tahun ajaran 2016/2017. Tujuan dari penelitian yaitu untuk mengetahui peningkatan kreativitas dan hasil belajar peserta didik mata pelajaran sejarah dengan menerapkan model NHT dalam proses pembelajaran dengan media Hypertext. Harapan penelitian ini yaitu dapat dimanfaatkan oleh pendidik, peserta didik, sekolah, dan bagi pihak lain yang ingin melakukan penelitian yang sama, dan juga diharapkan pendidik menjadi kreatif dalam proses pembelajaran.

\section{Metode Penelitian}

Jenis penelitian yang digunakan adalah penelitian tindakan kelas (PTK) dan desain menggunakan rancangan Hopkin yang dilakukan sebanyak 3 putaran. Setiap siklus dilakukan dengan 4 tahapan [3]. Setiap siklus dilakukan sebanyak 2 pertemuan selama $3 \times 45$ menit, kemudian dilanjutkan dengan refleksi hasil setiap siklus. Siklus dilakukan sejak tanggal 21 Maret hingga 28 April 2017. Materi yang digunakan yaitu berkembangnya nasionalisme di Indonesia, kependudukan Jepang di Indonesia, persiapan untuk kemerdekaan NKRI. Subyek penelitian yaitu kelas XI IPS 1 SMAN 1 Jenggawah dengan jumlah 40 peserta didik.

Peneliti menggunakan beberapa metode untuk mengumpulkan data yaitu: observasi, angket, wawancara, dokumenter, tes. Langkah-langkah penelitian adalah:

1. Kebutuhan Awal

Kebutuhan awal adalah tindakan yang dilakukan untuk memperoleh data awal sebagai landasan dari penelitian [4]. Analisis data yang dibutuhkan yaitu dokumentasi nilai peserta didik, wawancara awal sebelum tindakan kepada pendidik dan peserta didik terhadap permasalahan yang ada di lapangan, dan penyebaran angket untuk mengetahui kondisi awal kreativitas peserta didik. Pemasalahan yang muncul yaitu: (1) peserta didik kurang kreatif dalam mengajukan pertanyaan; (2) peserta didik cenderung kurang aktif dalam memperhatikan penjelasan pendidik, cenderung tidak menjawab pertanyaan yang diajukan pendidik maupun pada saat berdiskusi; (3) peserta didik kebanyakan takut untuk bertanya terhadap materi yang kurang di pahami kepada pendidik, hal tersebut dikarenakan peserta didik memiliki rasa keingintahuan yang kurang akan materi pelajaran yang sedang dipelajari; dan (4) pendidik hanya menggunakan model ceramah dalam pembelajaran.

2. Perencanaan

Tahap perencanaan meliputi kegiatan : (1) membuat rencana pelaksanaan pembelajaran; (2) membuat instrumen tes dan kunci jawaban (3) mempersiapkan media pembelajaran sejarah berupa materi di media Hypertext; (4) mempersiapkan lembar angket; (5) membagi kelompok kerja secara heterogen.

\section{Tindakan}

Kegiatan tindakan dilakukan sebagai upaya untuk memperbaiki dan meningkatkan hasil belajar dan kreativitas peserta didik. Tindakan dilakukan dengan menggunakan langkah pembelajaran NHT dengan menggunakan media hypertext, yaitu: penjelasan materi dengan menggunakan media hypertext oleh pendidik, pendidik memberikan nomor kepada setiap peserta didik dalam kelompok, pendidik memberi soal kepada peserta didik untuk di diskusikan bersama anggota kelompok dan setiap peserta didik harus menguasai dan memahami jawaban dari setiap soal. Selanjutnya pendidik memanggil peserta didik berdasarkan nomor untuk menjawab soal.

\section{Obseravasi}

Observasi dilakukan oleh 5 observer sebagai acuan untuk melihat aktivitas peserta didik pada saat proses pembelajaran. Hasil dari observer ini dijadikan sebagai patokan nanti apakah peserta didik jujur dalam menjawab angket yang akan diberikan pada saat akhir pembelajaran. Selain itu observasi 
juga dilakukan pada pendidik pada saat mengajar selama proses pemblajaran.

5. Angket

Angket dilakukan pada saat akhir proses pembelajaran dimana peserta didik mengisi angket sesuai dengan perlakuan yang peserta didik selama proses pembelajaran.

6. Refleksi

Refleksi merupakan kegiatan mengkaji segala hal yang telah terjadi selama pelaksanaan tindakan dari observasi dan hasil tes peseta didik yang digunakan untuk melihat peningkatan hasil nilai dan kreativitas peserta didik setelah dilaksanakan pembelajaran model pembelajaran numbered head together dengan media Hypertext sudah berjalan baik atau belum. Analisis refleksi yang sudah didapat sebagai pertimbangan sebagai acuan untuk merencanakan dan melaksanakan tindakan berikutnya yang lebih baik lagi. Penilaian kreativitas dilakukan sesuai dengan indikator: kelancaran berpikir, keluwesan berpikir, berpikir orisinil, dan berpikir elaborasi dengan kriteria sangat kreatif (SK), kreatif $(\mathrm{K})$, cukup kreatif $(\mathrm{CK})$, dan kurang kreatif(KK). Penilaian hasil belajar diukur dengan acuan skala likert dengan kriteria sangat baik, baik, cukup baik, dan kurang baik.

\section{Hasil Penelitian dan Pembahasan}

Penelitian dilakukan di SMAN 1 Jenggawah kelas XI IPS 1 pada semester genap tahun akademik 2016/2017 yang bertujuan untuk mengetahui kreativitas dan hasil belajar sejarah dengan menerapkan model pembelajaran kooperatif tipe numbered head together dengan media hypertext. Hasil penelitian yang dilaksanakan sebanyak 3 siklus ini, dimana setiap siklus dilakukan dua kali pertemuan selama $3 \times 45$ menit, kemudian dilanjutkan dengan refleksi hasil setiap siklus. Berikut penjelasan dari: (1) hasil kegiatan pra siklus pada hari Senin tanggal 5 Desember 2016; (2) hasilkegiatan penelitian siklus 1 dilaksanakan hari Selasa tanggal 21 Maret 2017 dan hari Jumat tanggal 24 Maret 2017; (3) hasil kegiatan penelitian siklus 2 dilaksanakan yaitu pada hari Selasa tanggal 4 April 2017 dan hari Jumat tanggal 7 April 2017; dan (4) hasil kegiatan penelitian siklus 3 pada hari Selasa tanggal 25 April 2017 dan Jumat 28 April 2017.

Pengukuran kreativitas dilakukan dengan menggunakan angket yang diberikan kepada peserta didik pada saat akhir pembelajaran di setiap siklus. Hasil angket tersebut dijadikan hasil kreativitas peserta didik. Adapun hasil kreativitas peserta didik yang diperoleh:

Tabel 1. Hasil Kreativitas Peserta Didik

\begin{tabular}{lcccc}
\hline Indikator & \multicolumn{2}{c}{ Pra Siklus Siklus I } & Siklus II & Siklus III \\
\hline $\begin{array}{l}\text { Kelancaran } \\
\text { Berpikir }\end{array}$ & $58,00 \%$ & $64,00 \%$ & $66,00 \%$ & $70,00 \%$ \\
\hline $\begin{array}{l}\text { Keluwesan } \\
\text { Berpikir }\end{array}$ & $61,00 \%$ & $65,00 \%$ & $67,00 \%$ & $72,00 \%$ \\
\hline Berpikir & $61,00 \%$ & $66,00 \%$ & $68,00 \%$ & $75,00 \%$ \\
Orisinil & & & & \\
\hline $\begin{array}{l}\text { Berpikir } \\
\text { Elaborasi }\end{array}$ & $59,00 \%$ & $65,00 \%$ & $67,00 \%$ & $72,00 \%$ \\
\hline
\end{tabular}

Hasil Belajar diperoleh dengan cara pemberian tes essai di setiap akhir siklus pembelajaran. Peningkatan hasil belajar peserta didik pada aspek kognitif meningkat apabila kreativitas selama proses pembelajaran peserta didik meningkat. Aspek kognitif peserta didik dapat diukur melalui tes setelah pelaksanaan pembelajaran pada setiap siklus. Hasil analisis tes peserta didik yang nantinya sebagai nilai hasil belajar peserta didik yaitu:

Tabel 2. Analisis Hasil Belajar Aspek Kognitif Setiap Siklus

\begin{tabular}{|c|c|c|c|c|c|}
\hline \multicolumn{2}{|c|}{ Rata-rata } & Peningkatan & \multicolumn{2}{|c|}{ Rata-rata } & Peningkatan \\
\cline { 4 - 5 } $\begin{array}{c}\text { Siklus } \\
1\end{array}$ & Siklus 2 & & Siklus 2 & Siklus 3 & $(\%)$ \\
\hline $69,65 \%$ & $75,73 \%$ & $8,72 \%$ & $75,73 \%$ & $76,89 \%$ & $4,97 \%$ \\
\hline
\end{tabular}

Terdapat empat indikator yang diukur pada kreativitas peserta didik, dimana setiap indikator juga mengalami peningkatan cukup pesat setelah dilakukan penerapan model pembelajaran kooperatif tipe NHT dengan media hypertext. Adapun hasil pengukuran dari masing-masing indikator kreativitas adalah sebagai berikut:

1.Kelancaran Berpikir

Tabel 3. Hasil Peningkatan Kreativitas Pada Indikator Kelancaran Berpikir

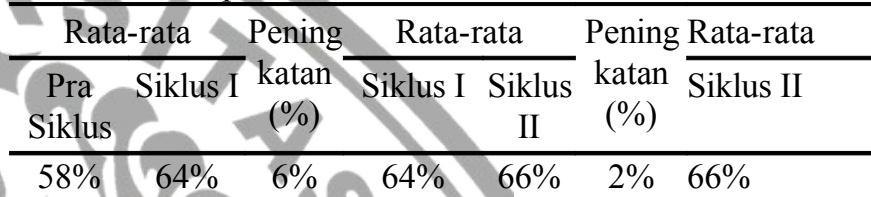

Berdasarkan tabel 3. peningkatan kreativitas peserta didik pra siklus pada indikator kelancaran berpikir dapat diketahui jumlah persentase $58 \%$ dengan kriteria kurang kreatif meningkat $6 \%$ menjadi $64 \%$ pada siklus 1 dengan kriteria cukup kreatif. Pada siklus 2 meningkat sebesar 2\% dari $64 \%$ menjadi $66 \%$ dengan kriteria cukup kreatif. Pada siklus 3 meningkat lagi sebesar $4 \%$ dari $66 \%$ pada siklus 2 menjadi $70 \%$ pada siklus 3 dengan kriteria kreatif. Berdasarkan hasil diatas, indikator kelancaran berpikir menunjukkan adanya peningkatan pada setiap siklusnya.

2.Keluwesan Berpikir

Tabel 4. Peningkatan Kreativitas Indikator Keluwesan Berpikir

\begin{tabular}{cccccc}
\hline Rata-rata & Peningkatan & \multicolumn{3}{c}{ Rata-rata } & Peningkatan \\
\cline { 3 - 4 } & Siklus I Siklus & $(\%)$ & Siklus & Siklus & $(\%)$ \\
II & \multicolumn{4}{c}{ II } & III \\
\hline $65,00 \%$ & $67,00 \%$ & $2,00 \%$ & $67,00 \%$ & $72,00 \%$ & $5,00 \%$ \\
\hline
\end{tabular}

Berdasarkan tabel 4. peningkatan kreativitas peserta didik siklus 1 pada indikator keluwesan berpikir dapat diketahui jumlah persentase $65 \%$ dengan kriteria cukup kreatif meningkat $2 \%$ pada siklus 2 menjadi $67 \%$ dengan kriteria cukup kreatif. Pada siklus 3 meningkat sebesar 5\% dari $67 \%$ pada siklus 2 menjadi $72 \%$ siklus 3 dengan kriteria sudah kreatif. Berdasarkan hasil diatas, indikator keluwesan berpikir menunjukkan adanya peningkatan pada setiap siklus. 3. Berpikir Orisinil

Tabel 5. Peningkatan Kreativitas Indikator Berpikir Orisinil

\begin{tabular}{|c|c|c|c|c|}
\hline Rata-rata & \multirow{2}{*}{$\begin{array}{c}\text { Peningkatan } \\
(\%)\end{array}$} & \multicolumn{2}{|c|}{ Rata-rata } & \multirow{2}{*}{$\begin{array}{c}\text { Peningkatan } \\
(\%)\end{array}$} \\
\hline $\begin{array}{c}\text { Siklus I Siklus } \\
\text { II }\end{array}$ & & $\begin{array}{l}\text { Siklus } \\
\text { II }\end{array}$ & $\begin{array}{l}\text { Siklus } \\
\text { III }\end{array}$ & \\
\hline $66,00 \% 68,00 \%$ & $2,00 \%$ & $68,00 \%$ & $75,00 \%$ & $7,00 \%$ \\
\hline
\end{tabular}


Berdasarkan tabel 5. peningkatan kreativitas peserta didik siklus 1 pada indikator berpikir orisinil dapat diketahui jumlah persentase $66 \%$ dengan kriteria cukup kreatif meningkat $2 \%$ pada siklus 2 menjadi $68 \%$ dengan kriteria cukup kreatif. Pada siklus 3 meningkat sebesar 7\% dari $68 \%$ pada siklus 2 menjadi $75 \%$ siklus 3 dengan kriteria sudah kreatif. Berdasarkan hasil analisis diatas, indikator berpikir orisinil menunjukkan adanya peningkatan pada setiap siklusnya.

4.Berpikir Terperinci

Tabel 6. Peningkatan Kreativitas Indikator Berpikir Terperinci

\begin{tabular}{cccccc}
\hline \multicolumn{2}{c}{ Rata-rata } & Peningkatan & \multicolumn{2}{c}{ Rata-rata } & Peningkatan \\
\cline { 1 - 1 } Siklus I & Siklus & $(\%)$ & Siklus & Siklus & $(\%)$ \\
II & & II & III & \\
\hline $65,00 \%$ & $67,00 \%$ & $2,00 \%$ & $67,00 \%$ & $72,00 \%$ & $5,00 \%$
\end{tabular}

Berdasarkan tabel 6. peningkatan kreativitas peserta didik siklus 1 pada indikator berpikir terperinci dapat diketahui jumlah persentase $65 \%$ dengan kriteria cukup kreatif meningkat $2 \%$ pada siklus 2 menjadi $67 \%$ dengan kriteria cukup kreatif. Pada siklus 3 meningkat sebesar 5\% dari $67 \%$ pada siklus 2 menjadi $72 \%$ siklus 3 dengan kriteria sudah kreatif. Berdasarkan hasil analisis diatas, indikator berpikir terperinci menunjukkan adanya peningkatan pada setiap siklusnya.

\section{Hasil Belajar}

\section{1) Aspek Kognitif Siklus I}

Perolehan nilai hasil belajar peserta didik ranah kognitif diukur dari kemampuan peserta didik setelah mengikuti pelaksanaan pembelajaran melalui tes (essay) berupa ranah menganalisis (C4). Tes dilakukan pada akhir siklus berbentuk tes uraian yang di buat oleh peneliti dan pendidik sebelum melaksanakan tindakan. Hasil data pelaksanaan siklus 1 pada aspek kognitif diperoleh hasil data keterangan 21 peserta didik tuntas, dan yang belum tuntas 19 peserta didik. Ratarata hasil belajar siklus 1 sebesar 69,65. Persentase klasikal hasil belajar peserta didik ranah kognitif pada pelaksanaan siklus 1 sebesar $52,5 \%$.

Hasil belajar ranah kognitif oleh peserta didik pada pelaksanaan siklus 1 terjadi peningkatan dibanding dengan pelaksanaan pra siklus. Penerapan model pembelajarn NHT dengan media hypertext merupakan hal baru bagi peserta didik kelas XI IPS 1 SMAN 1 Jenggawah, karena sebelum pelaksanaan tindakan pendidik hanya menerapkan metode ceramah, dengan menggunakan media papan tulis sebagai alat menyampaikan materi.

Pelaksanan siklus 1 peserta didik masih belum terbiasa dengan model pembelajaran yang digunakan, akan tetapi diharapkan pada pelaksanaan berikutnya peserta didik sudah mulai terbiasa. Pada saat pembelajaran berlangsung peserta didik memperhatikan tayangan media hyperlink dengan antusias dibandingkan dengan pembelajarn pada pra siklus. Peserta didik sudah mulai merumuskan jawaban dari pertanyaan yang diberikan oleh pendidik, meskipun masih ada yang merasa takut untuk bertanya dan masih takut untuk menjawab pertanyaan dari pendidik, masih takut untuk merumuskan permasalahan, memberikan ide dan gagasan. Dalam pelaksanaanya masih ada peserta didik yang ramai sendiri, hal tersebut menjadi evaluasi pada pelaksanaan siklus 2.

2) Aspek Kognitif Siklus 2

Berdasarkan penelitian yang dilakukan pada siklus 2, perolehan nilai hasil belajar peserta didik ranah kognitif diukur dari kemampuan peserta didik setelah mengikuti pelaksanaan pembelajaran melalui tes (essay) berupa ranah menganalisis (C4). Tes dilakukan pada akhir siklus berbentuk tes uraian yang di buat oleh peneliti dan pendidik sebelum melaksanakan tindakan. Hasil data pelaksanaan siklus 2 dengan menerapkan model pembelajaran kooperatif tipe NHT dengan media hypertext, aspek kognitif dinyatakan tuntas dan meningkat dari siklus 1 dengan ketuntasan secara klasikal sebesar 76,31\%. Ketuntasan meningkat 45,35\% dari siklus 1 dan 29 peserta didik dikatakan tuntas dan yang tidak tuntas berjumlah 9 peserta didik. Dapat disimpulkan pada siklus 2 ini telah terjadi peningkatan pada hasil belajar peserta didik.

Peningkatan yang terjadi pada siklus 2 didapat dari pemahaman peserta didik tentang langkah pembelajaran dengan model numbered head together menggunakan media hypertext, sehingga peserta didik mulai serius mengikuti pembelajaran. Pada pelaksanaan pembelajaran siklus 2 peserta didik sudah mulai mengalami peningkatan, peserta didik sudah sedikit mengutarakan gagasan dan ide kepada kelompok laon ketika presentasi, dan memberikan jawaban tambahan kepada kelompok yang sedang berpresentasi. Pembelajaran sudah mengalami peningkatan, sehingga ketika pendidik memberikan tes di akhir pembelajaran, peserta didik sudah siap dan dibuktikan dengan jawaban pada tes siklus 2 sudah banyak yang benar meskipun masih ada beberapa yang kurang. Sehingga hasil belajar yang dipeorleh peserta didik pada siklus 2 lebih baik dibandingkan dengan pelaksanaan siklus 1.

3) Aspek Kognitif Siklus 3

Berdasarkan hasil penilaian aspek kognitif pada tes silus 3, hasil belajar peserta didik ranah kognitif di ukur dari kemampuan peserta didik ranah menganalisis (C4) yang diperoleh setelah melaksanakan pembelajaran melalui tes tulis (essay) berbentuk uraian yang telah dibuat oleh peneliti bersama pendidik. Siklus 3 peningkatan sebesar $82.05 \%$, dengan keterangan 32 tuntas dan 7 tidak tuntas.

Dari hasil siklus 1 dan siklus 2, siklus 3 sudah menunjukkan peningkatan yang baik. Pendidik sudah melaksanakan semua langkah-langkah pembelajara yang sudah dibuat pada rencana pelaksanaan pembelajaran. Pendidik sudah membimbing peserta didik dengan baik selama proses pembelajaran. Peserta didik juga sudah meninjolkan kraetivitasnya dalam proses pembelajaran. Peserta didik sudah tidak malu untuk bertanya, menjawab, dan mengeluarkan pendapat kepada keompok lain ketika sedang presentasi. Ketika sedang berdiskusi peserta didik sudah mulai fokus dan sudah berani mengeluarkan gagasannya kepada teman kelompok. Pada siklus 3 ini kreativitas peserta didik sudah menunjukkan hasil yang baik sehingga berdampak pada hasil belajar ranah kognitif meningkat yang dilaksanakan pada akhir pembelajaran.

\section{Kesimpulan dan Saran}

Kesimpulan 
Berdasarkan rumusan masalah yang telah di buat oleh peneliti, adapun hasil penelitian dan pembahasan yang diperoleh, peneliti mengambil kesimpulan:

1. Penerapan model pembelajaran kooperatif tipe numbered head together dengan media hypertext dapat meningkatkan kreativitas peserta didik dalam pembelajaran sejarah di kelas XI IPS 1 SMAN 1 Jenggawah semester genap tahun ajaran 2016/2017. Kreativitas peserta didik diukur melalui hasil angket dengan indikator: 1) kelancaran berpikir; 2) keluwesan berpikir; 3) berpikir orisinil; 4) berpikir terperinci. Presentase kreativitas siklus 1 sebesar $63 \%$ dengan kriteria cukup kreatif. Pada pelaksanaan siklus 2 memperoleh persentase sebesar $69 \%$ dengan kriteria cukup kreatif, siklus 2 mengalami peningkatan sebesar $6 \%$ dari $63 \%$ menjadi $69 \%$. Pada pelaksanan siklus 3 memperoleh persentase sebesar $71 \%$ dengan kriteria kreatif. Terjadi peningkatan sebesar $2 \%$ dari $69 \%$ menjadi $71 \%$.

2. Penerapan model pembelajaran kooperatif tipe numbered head together dengan media hypertext dapat meningkatkan hasil belajar peserta didik dalam pembelajaran sejarah di kelas XI IPS 1 SMAN 1 Jenggawah semester genap tahun ajaran 2016/2017. Aspek kognitif dapat diperoleh melalui tes (essay) yang dilakuakn setelah pelaksanaan pembelajaran berupa soal uraian yang dibuat oleh peneliti bersama penidik dengan mengukur kemampuan peserta didik ranah menganalisis (C4). Secara klasikal hasil belajar siklus 1 sebesar $52,5 \%$. Siklus 2 memperoleh ketuntasan secara klasikal sebesar $76,31 \%$ sehingga terjadi peningkatan sebesar $45,35 \%$ dari siklus 1 . Terjadi peningkatan dari siklus 2 ke siklus 3 sebesar 7,52\% dari 76,31\% menjadi $82,05 \%$.

3. Tindakan dilakukan sebanyak 3 tahapan atau 3 siklus. Siklus 1 dilakukan dengan menggunakan perencana yang sudah disusun awal oleh peneliti bersama pendidik. Pelaksanaan siklus 1 masih banyak kekurangan sehingga dilaksanakan siklus 2. Siklus 2 dilakukan dengan perencanaan lebih matang yaitu dilakukan perbaikan dengan cara pendidik lebih membimbing peserta didik dalam berkelompok, dan pelaksanaan siklus 3 dilakukan dengan perbaikan pendidik memperbaiki media hypertext dengan materi yang menarik sehingga memunulkan kreativitas peserta didik dalam hal bertanya dan lebih memfokuskan lagi dalam membimbing peserta didik sehingga dengan pelaksanaan siklus 3 ini peserta didik memgalami peningkatan baik dari kreativitas dan hasil belajar.

\section{Saran}

Sesuai dengan penjelasan di atas maka peneliti memberi masukan saran, yaitu bagi peserta didik Peserta didik yang mendapatkan nilai kreativitas dan hasil belajar rendah sebaiknya harus lebih aktif lagi, belajar lebih giat dalam proses pembelajaran, dan terus semangat agar kreativitas dan hasil belajar dapat meningkat menjadi lebih baik lagi. Pihak sekolah dan pendidik sebaiknya lebih mengutamakan peran peserta didik dalam pembelajaran, tinggalkan metode lama dengan menerapkan metode pembelajaran yang baru. Dan untuk peneliti hendaknya mencari referensi yang lebih banyak lagi sehingga dalam penulisannya menjadi lebih baik.

\section{Daftar Pustaka}

[1] Hamid, A. R. 2014. Pembelajaran Sejarah. Yogyakarta: Ombak.

[2] Komara, E. 2014. Belajar dan Pembelajaran Interaktif. Bandung: Refika Aditama.

[3] Arikunto, S., dkk. 2009.Penelitian Tindakan Kelas. Jakarta: Bumi Aksara

[4] Arikunto, S. 2002. Prosedur Penelitian Suatu Pendekatan Praktek. Edisi Revisi. Jakarta: Bumi Aksara. 